IFAS Extension

\title{
Food Safety: HIGH-RISK FOODS ${ }^{1}$
}

Jennifer Hillan $^{2}$

Some foods are more likely to cause foodborne illness than others.

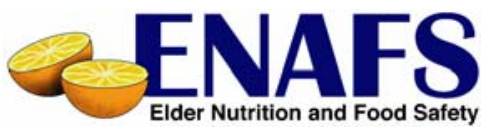

Stay away from these high-risk foods:

\section{Across}

3. Foods made with raw like Hollandaise sauce, cookie dough, and cake batter.

4. Other foods made with raw egg, like homemade salad dressing and homemade ice cream.

6. Unpasteurized and fruit juices.

\section{Down}

1. Raw and undercooked fish and shellfish, like raw

2. Soft made from unpasteurized milk, like feta, Brie, and Camembert.

5. Raw sprouts, like sprouts.
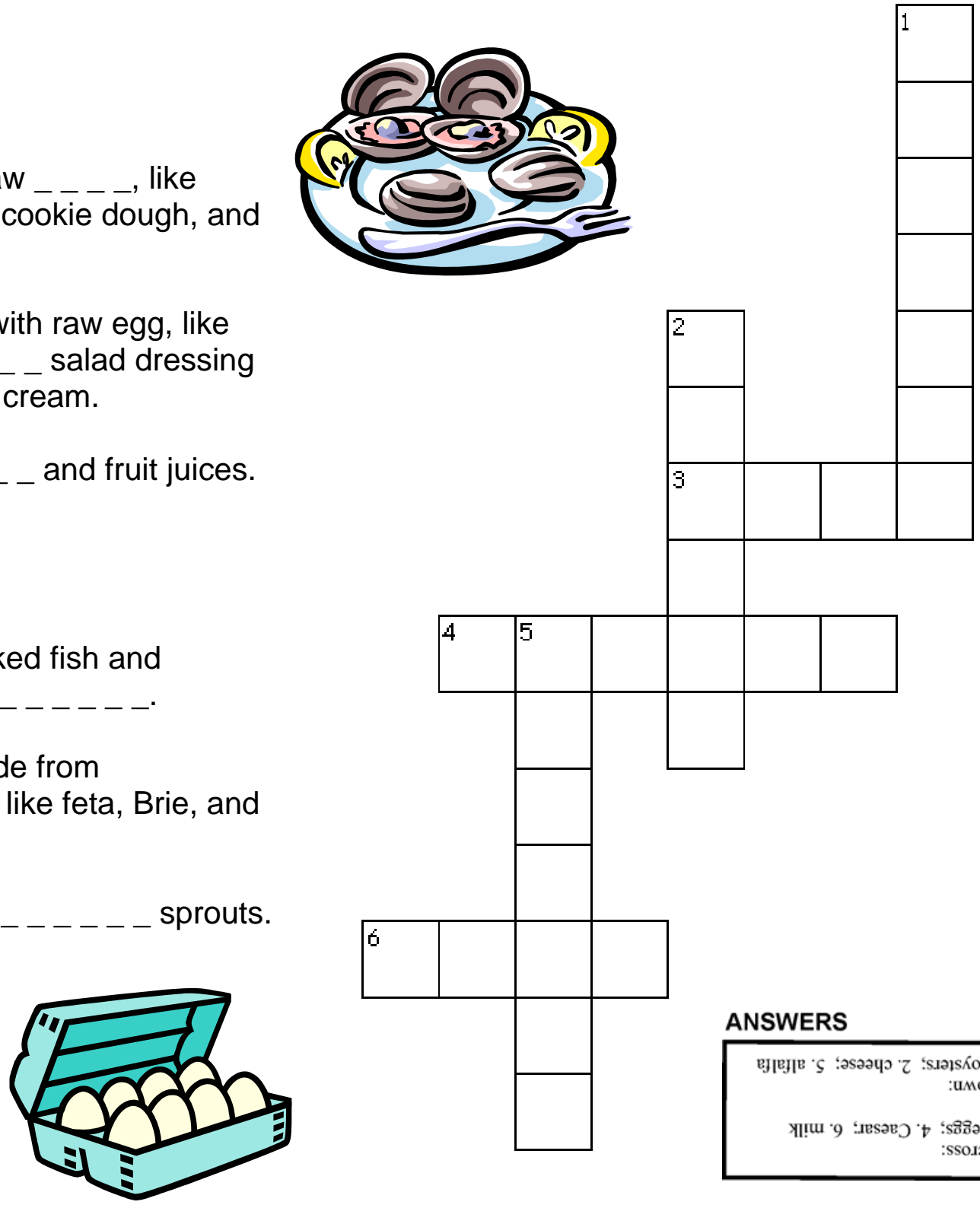

\section{ANSWERS}

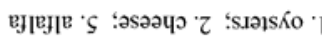
:unod

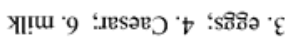
SSO.10

1. La versión en español de este documento es Cuidado de Alimentos: Alimentos de Alto Riesgo (FCS8802-Span). This document, FCS8802, is one in a series of the Department of Family, Youth and Community Sciences, Florida Cooperative Extension Service, IFAS, University of Florida, Gainesville, FL 32611. First published: April 2007. Please visit the EDIS Website at http://edis.ifas.ufl.edu

2. Jennifer Hillan, MSH, RD, LD/N, ENAFS nutrition educator, Department of Family, Youth and Community Sciences, Florida Cooperative Extension Service, Institute of Food and Agricultural Sciences, University of Florida, Gainesville, FL 32611.

The Institute of Food and Agricultural Sciences (IFAS) is an Equal Opportunity Institution authorized to provide research, educational information and other services only to individuals and institutions that function with non-discrimination with respect to race, creed, color, religion, age, disability, sex, sexual orientation, marital status, national origin, political opinions or affiliations. For more information on obtaining other extension publications, contact your county Cooperative Extension service. U.S. Department of Agriculture, Cooperative Extension Service, University of Florida, IFAS, Florida A. \& M. University Cooperative Extension Program, and Boards of County Commissioners Cooperating. Larry Arrington, Dean. 